\title{
Risk of Smoking in Patients with Malignant Tumor: Study in Bangabandhu Sheikh Mujib Medical University, Dhaka, Bangladesh
}

\author{
Farhad Mahmud ${ }^{1 *}$, Shahnaz Parvin ${ }^{2}$, Farzana Rahman $^{3}$, Mridul Kumar Saha ${ }^{4}$
}

${ }^{1}$ Assistant Professor, Department of Pathology, Colonel Malek Medical College, Manikganj, Bangladesh

${ }^{2}$ Assistant professor, Department of Pathology, Shaheed Suhrawardy Medical College, Sher E Bangla Nagar, Dhaka, Bangladesh

${ }^{3}$ Assistant Professor, Department of Pathology, National Institute of Traumatology and Orthopedic Rehabilitation, Dhaka, Bangladesh

${ }^{4}$ Assistant Professor(CC), Department of Pathology, Colonel Malek Medical College, Manikganj, Bangladesh

DOI: $10.36347 /$ sjams.2020.v08i06.032

| Received: 02.06.2020 | Accepted: 22.06.2020 | Published: 27.06.2020

*Corresponding author: Dr. Farhad Mahmud

Abstract

Original Research Article

Introduction: Like many other countries in the world cancer in Bangladesh is one of the major killer diseases. Along with many other countries, Bangladesh has an increasing number of cancers, primarily because of cigarette smoking, chewing of betel nut/betel leaf and exposure to several oncogenic microorganisms and other carcinogens ubiquitous and also for coupled with lack of screening, awareness and poor health seeking behaviors associated with poverty, malnutrition, and illiteracy. Aim of the study: To assess the risk of smoking in patients with malignant tumor. Material \& Methods: This is a cross sectional study conducted at the Department of Pathology, Bangabandhu Sheikh Mujib Medical University, Dhaka from October 2011 to September 2012. All tumor cases diagnosed by histopathology or cytopathology in the department of Pathology, BSMMU were enrolled in this study. The materials for diagnoses were biopsy specimens, surgical resection/excised specimens, and cytology specimens. All tumor reports were stored in computer data base and would be retrieved according to need. Information was collected from the patients or close relatives of the patients. Personal identification data and tumor related information including ICD-O3 and ICD 10 were collected and recorded systematically in a data abstraction sheet. Tumor identification part was filled up by a resident doctor. All precautions were maintained to avoid multiple counts of same patient. These data were entered in to software by using Microsoft access. Basic frequency distribution and proportion of data were presented in tables, figures and diagrams. Statistical analyses of the results will be obtained by using window based computer software devised with Statistical Packages for Social Sciences (SPSS-15). Results: Of the total696 cancer cases, 354 were smokers. $50.9 \%$ were smoker and $49.1 \%$ were nonsmoker. In smoker's squamous cell carcinoma represented highest figures of $112(31.64 \%)$, followed by adenocarcinoma 88(24.86\%), ductal carcinoma of breast 17 (4.81\%), urothelial carcinoma $15(4.24 \%)$, papillary carcinoma of thyroid $14(3.95 \%)$, hepatocellular carcinoma $14(3.95 \%)$ and lymphoma $13(3.67 \%)$. Male patients were more smoker than female. Oral cavity ranked the first followed by oropharynx, larynx, oesophagus, etc. in different sites of squamous cell carcinoma. Of all the total 696 cancer cases, 235 were non smoke tobacco consumers. $42.38 \%$ were non smoke tobacco consumers and $57.62 \%$ were not. Squamous cell carcinoma represented highest figures of $123(52.34 \%)$, followed by adenocarcinoma 47(20\%), ductal carcinoma of breast $22(9.36 \%)$, urothelial carcinoma $05(2.12 \%)$, papillary carcinoma of thyroid $12(5.10 \%)$, hepatocellular carcinoma $09(3.82 \%)$ and lymphoma $(1.27 \%)$. Female patients were more nonsmoking consumers than male. Oral cavity ranked the first followed by oropharynx, cervix, oesophagus, etc in different sites of squamous cell carcinoma. Stomach represented the highest followed by colon and rectum in different sites of adenocarcinoma. Conclusion: To control cancer proper data on cancer trend is essential. Cancer registry is the system which can provide such information.

Keywords: Smoking, Malignant Tumor, Pathology, Squamous Cell Carcinoma.

Copyright @ 2020: This is an open-access article distributed under the terms of the Creative Commons Attribution license which permits unrestricted use, distribution, and reproduction in any medium for non-commercial use (NonCommercial, or CC-BY-NC) provided the original author and source are credited.

\section{INTRODUCTION}

Like many other countries in the world cancer in Bangladesh is one of the major killer diseases. Along with many other countries, Bangladesh has an increasing number of cancers, primarily because of cigarette smoking, chewing of betel nut/betel leaf and exposure to several oncogenic microorganisms and other carcinogens ubiquitous and also for coupled with lack of screening, awareness and poor health seeking behaviors associated with poverty, malnutrition, and illiteracy. IARC has projected (2002) the death from 10 leading cancers in females of Bangladesh are mouth and 
oropharyngeal, cervical, breast, esophageal, ovarian, lung cancer, lymphoma, stomach, liver, colorectal cancer and in males are mouth and oropharyngeal, lung cancer, esophageal, lymphoma, stomach, bladder, liver cancer, leukemia, colo-rectal and prostate cancer. The threats of both benign and malignant tumors are increasing all over the world including Bangladesh. Bangladesh is still lacking an effective national tumor registry. Like many other countries few attempts were made in Bangladesh, but they did not succeed. Establishment of tumor registry in Bangladesh like many other countries faces some problems. These include lack of awareness, insufficient quality of most registries, weak infrastructure, inadequate coverage, and difficulty in sustainability due to insufficient financial support and turnover of trained personnel, few opportunities for education and training etc. Establishment of tumor registry is a difficult task. A hospital based tumor registry started in 1967 at Dhaka Medical College Hospital and continued till 1971. There have been several attempts since then but all failed to sustain. As pathology centers in Bangladesh maintain good communication and keep record, idea of a pathology based tumor registry was conceived. It would start as a pilot project, as a pathology based tumor registry cell at BSMMU. As a tertiary level health care referral centre, people come here for treatment facilities from all over Bangladesh. Yearly about four and a half thousand non- hematological tumors are handled at the department of pathology of BSMMU. Through this project an infrastructure will be developed and experience gained will help in subsequent development of a registry network. It will also create a small one-year data of tumors recorded at BSMMU. A recent WHO study has estimated that there are 49,000 oral cancers, 71,000 laryngeal cancer and 196,000 lung cancer cases in Bangladesh, among those aged 30 years or above. The same study has also observed that $3.6 \%$ of the admissions in medical college hospitals for the same age group are due to cancers of oral cavity, larynx and lungs (WHO, 2007). Lung cancer in males, and cervical and breast cancer in females constitute $38 \%$ of all cancers in Bangladesh. One of the main primary risk factor for the development of upper aero digestive tract malignancies is smoking [1]. It is estimated by the American Cancer Society that, 27,700 incident malignancies of the oral cavity and pharynx and 9500 laryngeal malignancies will be diagnosed in the United States in 2003 [2]. More than $80 \%$ of all head and neck malignancies diagnosed each year are linked to tobacco use [1, 3, 4]. A history of smoking at the diagnosis of the index cancer is a universally recognized risk factor for second malignancy among patients with head and neck squamous cell carcinoma (HNSCC), with intense tobacco use having an especially notable cumulative effect on risk in this setting [5-9]. However, maximum studies estimating the effects of tobacco smoking on second primary tumor (SPT) risk have been crosssectional investigations $[10,11]$. In spite of having high morbidity and mortality from many cancers (e.g., lung, head and neck, liver and stomach cancers), there are no reliable data for the incidence, prognosis, morbidity, and mortality of cancers in Bangladesh.

\section{Methodology and Materials}

This is a cross sectional study conducted at the Department of Pathology, Bangabandhu Sheikh Mujib Medical University, Dhaka from October 2011 to September 2012. The study had two parts: 1 . Establishment of pathology based tumor registry (PBTR) at BSMMU; 2. Analysis of data gathered during the study period. All tumor cases diagnosed by histopathology or cytopathology in the department of Pathology, BSMMU were enrolled in this study. About 12,000 histopathology specimens are received each year. Similarly, many patients come for cytopathology. It is therefore a very suitable place to start a pathology based tumor registry. With this aim, pathology department started planning a registry. The BSMMU administrative authority encouraged the move. The materials for diagnoses were biopsy specimens, surgical resection/excised specimens, and cytology specimens. The adult and paediatrics haematology departments of BSMMU are under separate administration and pulmonology is in its developing phase. Therefore, hematological malignancy and lung cancer cases were not included at this phase. Suspicious cases of tumor or cases of tumor not diagnosed by histopathology or cytopathology were also not included. All tumor reports were stored in computer data base and would be retrieved according to need. Information was collected from the patients or close relatives of the patients. They were explained about tumor registry and a verbal consent was taken from the patient/ patient's guardian to be included in the study. Personal identification data and tumor related information including ICD-O3 and ICD 10 were collected and recorded systematically in a data abstraction sheet. Tumor identification part was filled up by a resident doctor. All precautions were maintained to avoid multiple counts of same patient. Data collected methodically and meticulously from October 2011 to September 2012 as far as questionnaire. These data were entered in to software by using Microsoft access. With the help of this software a master database was developed. Then data were categorized according to age group, gender, anatomical sites, benign or malignant tumor, occupation, risk behavior, socioeconomic condition and tumor identification. Sub set of data such as religion, geographical subdivision, rural and urban areas, etc were categorized. Basic frequency distribution and proportion of data were presented in tables, figures and diagrams. Statistical analyses of the results will be obtained by using window based computer software devised with Statistical Packages for Social Sciences (SPSS-15). 


\section{RESULTS}

Among 3657 cases, 2559 were malignant (69.98\%), 1098 (30.02\%0) were benign. Among malignant tumors, $11(0.43 \%)$ cases were of low malignant potential, $17(0.66 \%)$ were borderline malignancy, $28(1.09 \%)$ cases included carcinoma insitu or intraepithelial/noninvasive malignancy, 58 $(2.27 \%)$ were uncertain whether benign or malignant, $2034(79.48 \%)$ cases were primary malignant tumors and $404(15.79 \%)$ were secondary malignant tumors (Table-1). Of the total cases, $1549(42.36 \%)$ were male and $2108(57.64 \%)$ were female. The male: female ratio was 1: 1.36. In 2034 malignant tumor cases, were divided into age group decades. The age range was from 2 to 85 years. Considering each decade, fifth decade contained highest number of cases followed by sixth and fourth decade. The age range was from 2 to 85 years mean $47.30 \pm 16.37$ with a range of $2-85$ years. Where the cases were divided into pediatric group $(\leq 15$ years) and adult group ( $>15$ years) among 2034 cancer patients, $1974(97.05 \%)$ patients were in adult group, 60 $(2.85 \%)$ in the pediatric group. Table-3 showed Sarcoma $16(26.66 \%)$ was the most frequent malignant tumor in pediatrics age group followed by nephroblastoma $8(13.33 \%)$. neuroblastoma $5(8.33 \%)$. Of the total cases, income $\leq 5000$ taka per month was in $294(42.2 \%)$, income range of $5001-10,000$ was in 243 $(34.9 \%)$, range of $10,001-15,000$ in $92(13.2 \%)$, and income $>15,000$ in $67(9.6 \%)$ cases. Table- 6 shows the distribution of malignant tumors according to income range (Table-4). Of the total696 cancer cases, 354 were smokers (Table-5). 50.9\% were smoker and $49.1 \%$ were nonsmoker. Table-7 showed in smoker's squamous cell carcinoma represented highest figures of 112 (31.64\%), followed by adenocarcinoma $88(24.86 \%)$, ductal carcinoma of breast $17(4.81 \%)$, urothelial carcinoma $15(4.24 \%)$, papillary carcinoma of thyroid 14 (3.95\%), hepatocellular carcinoma $14(3.95 \%)$ and lymphoma 13 $(3.67 \%)$. Table-6 showed male patients were more smoker than female. Table- 8 showed oral cavity ranked the first followed by oropharynx, larynx, oesophagus, etc. in different sites of squamous cell carcinoma. Table-9 showed stomach represented the highest followed by colon and rectum in different site of adenocarcinoma. Of all the total 696 cancer cases, 235 were non smoke tobacco consumers. Table- 9 showed $42.38 \%$ were non smoke tobacco consumers and $57.62 \%$ were not. Table-12 showed squamous cell carcinoma represented highest figures of 123 (52.34\%), followed by adenocarcinoma 47(20\%), ductal carcinoma of breast $22(9.36 \%)$, urothelial carcinoma $05(2.12 \%)$, papillary carcinoma of thyroid $12(5.10 \%)$, hepatocellular carcinoma $09(3.82 \%)$ and lymphoma (1.27\%). Tabl-11 showed female patients were more nonsmoking consumers than male. Table-13 showed oral cavity ranked the first followed by oropharynx, cervix, oesophagus, etc in different sites of squamous cell carcinoma. Table-14 showed stomach represented the highest followed by colon and rectum in different sites of adenocarcinoma. $302(43.4 \%)$ were housewives, $81(11.6 \%)$ were farmers, $80 \quad(11.5 \%)$ were professionals, $55(7.9 \%)$ were students, $44(6.3 \%)$ were business personel, $29(4.2 \%)$ were retired persons, 26 $(3.7 \%)$ were unemployed, $23(3.3 \%)$ were day laborers, $11(1.6 \%)$ were factory workers ,10 (1.4\%) were garment workers, $6(0.9 \%)$ were automobile drivers, $5(0.7 \%)$ were rickshaw puller and $35(3.0 \%)$ were others. Table-15 shows the distribution of malignant tumor according to occupation.

Table-1: Distribution of patients according to tumor behavior

\begin{tabular}{|l|l|l|}
\hline Tumor behavior & Frequency & Percentage \\
\hline Benign & 1098 & 30.02 \\
\hline Malignant & 2559 & 69.98 \\
\hline Uncertain whether benign or malignant & 58 & 1.58 \\
\hline Borderline malignancy & 17 & 0.47 \\
\hline Low malignant potential & 11 & 0.30 \\
\hline Carcinom in-situ & 28 & 0.76 \\
\hline Malignant, primary site & 2034 & 55.62 \\
\hline Malignant, secondary site & 404 & 11.05 \\
\hline Total & $\mathbf{3 6 5 7}$ & $\mathbf{1 0 0 . 0}$ \\
\hline
\end{tabular}

Fig-1: Sex distribution of patients

\begin{tabular}{|l|l|l|}
\hline Sex & Frequency & Percentage \\
\hline Male & 1549 & 42.36 \\
\hline Female & 2108 & 57.64 \\
\hline Total & 3657 & 100 \\
\hline
\end{tabular}




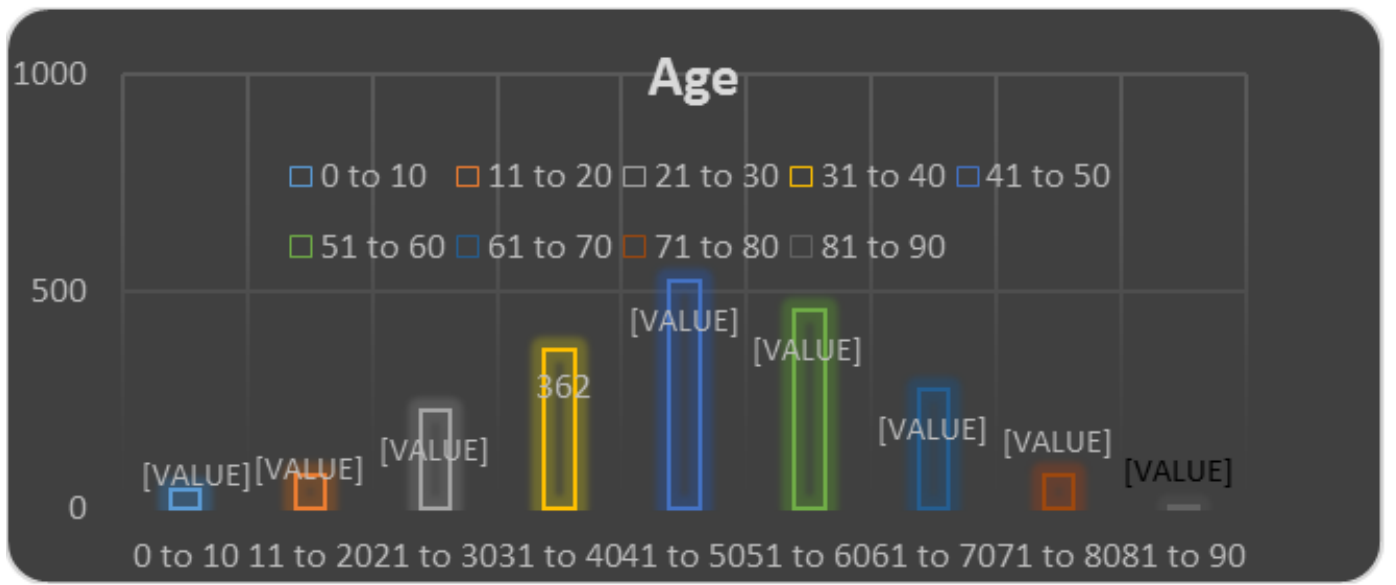

Fig-2: Age distribution of malignant tumor patients

Table-2: Distribution of malignant tumor according to age group

\begin{tabular}{|l|l|l|l|}
\hline \multicolumn{2}{|l|}{ Age group } & Frequency & Percentage \\
\hline Pediatric & $<15$ & 60 & 2.95 \\
\hline Adult & $15>$ & 1974 & 97.05 \\
\hline Total & 2034 & 100.00 \\
\hline
\end{tabular}

Table-3: Ranking of paediatric $(<15$ years) malignant tumors

\begin{tabular}{|l|l|l|}
\hline Site & Frequency & Percentage \\
\hline Sarcoma & 16 & 26.66 \\
\hline Nephroblastoma & 08 & 13.33 \\
\hline Neuroblastoma & 05 & 8.33 \\
\hline Papillary carcinoma of thyroid & 05 & 8.33 \\
\hline Hepatoblastoma & 04 & 6.66 \\
\hline Medulloblatoma & 04 & 6.66 \\
\hline Non Hodgkin lymphoma & 04 & 6.66 \\
\hline Others & 14 & 23.33 \\
\hline Total & $\mathbf{6 0}$ & $\mathbf{1 0 0 . 0}$ \\
\hline
\end{tabular}

Table-4: Distribution of malignant tumor according to socio economic condition (Income)

\begin{tabular}{|l|l|l|}
\hline Income range (Taka/month) & Frequency & Percentage \\
\hline$\leq 5000$ & 294 & 42.2 \\
\hline $5001-10,000$ & 243 & 34.9 \\
\hline $10,001-15,000$ & 92 & 13.2 \\
\hline$>15,000$ & 67 & 9.6 \\
\hline Total & $\mathbf{6 9 6}$ & $\mathbf{1 0 0 . 0}$ \\
\hline
\end{tabular}

Table-5: Distribution of malignant tumor according to smoking habit

\begin{tabular}{|l|l|l|}
\hline Smoking & Frequency & Percentage \\
\hline Yes & 354 & 50.9 \\
\hline No & 342 & 49.1 \\
\hline Total & $\mathbf{6 9 6}$ & $\mathbf{1 0 0 . 0}$ \\
\hline
\end{tabular}

Table-6: Distribution of malignant tumor according to male female ratio in smokers

\begin{tabular}{|l|l|l|l|}
\hline \multirow{2}{*}{ Smoking } & \multicolumn{2}{|l|}{ Sex } & \multirow{2}{*}{ Total } \\
\cline { 2 - 3 } & Male & Female & \\
\hline Yes & $311(87.85 \%)$ & $43(12.17 \%)$ & $354(100 \%)$ \\
\hline
\end{tabular}


Table-7: Diagnosis of malignant tumor according to smoking habit

\begin{tabular}{|l|l|l|}
\hline Diagnosis & Frequency & Percentage \\
\hline Squamous cell carcinoma & 112 & 32.20 \\
\hline Adenocarcinoma & 88 & 24.85 \\
\hline Papillary carcinoma of thyroid & 14 & 3.95 \\
\hline Ductal carcinoma of breast & 17 & 4.80 \\
\hline Lymphoma & 13 & 3.67 \\
\hline Hepatocellular carcinoma & 14 & 3.95 \\
\hline Urothelial carcinoma & 15 & 4.23 \\
\hline Others & 81 & 22.88 \\
\hline Total & $\mathbf{3 5 4}$ & $\mathbf{1 0 0}$ \\
\hline
\end{tabular}

Table-8: Distribution of Squamous cell carcinoma in different site of smokers

\begin{tabular}{|l|l|l|}
\hline Site & Frequency & Percentage \\
\hline Oral cavity & 45 & 40.17 \\
\hline Oropharynx & 23 & 20.11 \\
\hline Larynx & 13 & 11.29 \\
\hline Oesophagus & 10 & 9.82 \\
\hline Mandible & 08 & 7.24 \\
\hline Cervix & 06 & 5.36 \\
\hline Other & 07 & 6.25 \\
\hline Total & $\mathbf{1 1 2}$ & $\mathbf{1 0 0 . 0 0}$ \\
\hline
\end{tabular}

Table-9: Distribution of Adenocarcinoma in different site of smokers

\begin{tabular}{|l|l|l|}
\hline Site & Frequency & Percentage \\
\hline Stomach & 34 & 38.67 \\
\hline Colon and rectum & 29 & 32.95 \\
\hline Ampullary carcinoma & 11 & 12.5 \\
\hline Prostate & 06 & 6.8 \\
\hline Other & 08 & 9.09 \\
\hline Total & $\mathbf{8 8}$ & $\mathbf{1 0 0}$ \\
\hline
\end{tabular}

Table-10: Distribution of malignant tumor in nonsmoking tobacco consumers

\begin{tabular}{|l|l|l|}
\hline Tobacco & Frequency & Percentage \\
\hline Yes & 235 & 42.38 \\
\hline No & 461 & 57.62 \\
\hline Total & $\mathbf{6 9 6}$ & $\mathbf{1 0 0 . 0}$ \\
\hline
\end{tabular}

Table-11: Distribution of malignant tumor according to male female ratio in nonsmoking tobacco users

\begin{tabular}{|l|l|l|l|}
\hline \multirow{2}{*}{ Tobacco } & \multicolumn{2}{|l|}{ Sex } & \multirow{2}{*}{ Total } \\
\cline { 2 - 3 } & Male & Female & \\
\hline Yes & $104(44.26)$ & $131(55.74)$ & $\mathbf{2 3 5 ( 1 0 0 \% )}$ \\
\hline
\end{tabular}

Table-12: Diagnosis of malignant tumor according to nonsmoking tobacco consumers

\begin{tabular}{|l|l|l|}
\hline Diagnosis & Frequency & Percentage \\
\hline Squamous cell carcinoma & 123 & 52.34 \\
\hline Adenocarcinoma & 47 & 20.00 \\
\hline Ductal carcinoma of breast & 22 & 9.36 \\
\hline Papillary carcinoma of thyroid & 12 & 5.10 \\
\hline Hepatocellular carcinoma & 09 & 3.82 \\
\hline Urothelial carcinoma & 05 & 2.12 \\
\hline Lymphoma & 03 & 1.27 \\
\hline Others & 14 & 5.95 \\
\hline Total & $\mathbf{2 3 5}$ & $\mathbf{1 0 0}$ \\
\hline
\end{tabular}


Table-13: Distribution of Squamous cell carcinoma in different site of nonsmoking tobacco

\begin{tabular}{|l|l|l|}
\hline Site & Frequency & Percentage \\
\hline Oral cavity & 41 & 33.33 \\
\hline Oropharynx & 28 & 22.76 \\
\hline Cervix & 23 & 18.70 \\
\hline Oesophagus & 11 & 8.94 \\
\hline Larynx & 09 & 7.31 \\
\hline Other & 11 & 8.94 \\
\hline Total & $\mathbf{1 2 3}$ & $\mathbf{1 0 0}$ \\
\hline
\end{tabular}

Table-14: Distribution of Adenocarcinoma in different site of nonsmoking tobacco

\begin{tabular}{|l|l|l|}
\hline Site & Frequency & Percentage \\
\hline Stomach & 20 & 42.55 \\
\hline Colon and rectum & 10 & 21.27 \\
\hline Periampullary carcinoma & 08 & 17.02 \\
\hline Gallbladder & 07 & 14.89 \\
\hline Other & 03 & 6.38 \\
\hline Total & $\mathbf{4 7}$ & $\mathbf{1 0 0}$ \\
\hline
\end{tabular}

Table-15: Distribution of malignant tumor according to occupation

\begin{tabular}{|l|l|l|}
\hline Site & Frequency & Percentage \\
\hline House-wife & 302 & 43.4 \\
\hline Farmer & 81 & 11.6 \\
\hline Profession & 80 & 11.5 \\
\hline Student & 55 & 7.9 \\
\hline Business & 44 & 6.3 \\
\hline Retired & 29 & 4.2 \\
\hline Unemployed & 26 & 3.7 \\
\hline Day labor & 23 & 3.3 \\
\hline Factory & 11 & 1.6 \\
\hline Garments & 10 & 1.4 \\
\hline Automobile & 6 & .9 \\
\hline Rickshaw & 5 & .7 \\
\hline Others & 24 & 3.4 \\
\hline Total & $\mathbf{6 9 6}$ & $\mathbf{1 0 0 . 0}$ \\
\hline
\end{tabular}

\section{DiscuSSION}

Cancer is one of the leading cause of death among the non-communicable diseases. It has devastating effects on the society, country and mankind. With a cancer load of more than one million, Bangladesh is not an exception. According to Bangladesh Bureau of Statistics cancer is the sixth leading cause of death in Bangladesh (BBS, 2008). IARC anticipates that the incidence will increase day by day. Rapid urbanization, changes in life style and increased life expectancy are the underlying reasons. The distribution of benign and malignant tumors in the study showed predominance of malignant tumors constituting a majority of $69.98 \%$. The age range of the patients was from 2 to 85 years with a mean age of $47.30 \pm 16.37$ years. People in rural area are habituated with various forms of tobacco (Jarda, Biri Gul, Khaini), betel nut and betel leaf. These are carcinogenic and etiologically responsible for head neck cancers. At BSMMU the orofaciomaxillary department is well developed. So a good number of specimens were received. Cervical carcinomas were the second most common tumor in the present study, similar to Talukder et al., 12 In Pakistan, the Aga Khan University Hospital $(\mathrm{AKUH})$ showed that the relative frequency of the five commonest cancers in males were: cancer of the lung $(9.5 \%)$ followed by oral cavity $(9.1 \%)$, lymphomas (non-Hodgkin's lymphoma and Hodgkin's disease) $(8.4 \%)$, leukemia $(5.2 \%)$ and colo-rectum $(4.7 \%)$. This was followed by lymph node $7.9 \%$, esophagus $5.9 \%$ and larynx $5.4 \%$. IARC and cancer research, 2009 showed lung cancer continued to be the most common cancer diagnosed in men worldwide (accounting for $16.5 \%$ of all new cases). Cancer Incidence Report Nairobi 2000 - 2002 showed that Head and Neck group of cancers made up a large proportion comprising $14.8 \%$ of male cancers followed by prostate and stomach. In this current study oral cavity and oropharynx cancer was the highest in male followed by stomach, liver, colon and rectum and thyroid. Various studies including IARC showed that in female breast 
carcinoma was the number one. The AKUH study showed that highest frequency in female was breast, followed by oral cavity, ovary, lymphoma and colorectal carcinoma. In the present study the highest incidence of malignant tumor in female was the cervix (22\%) followed by the breast $(19 \%)$, thyroid (13\%), oral cavity $(13 \%)$ and colorectal $(05 \%)$. Several studies showed that cervical carcinoma now declining in developed countries but still ranking top in developing countries. It is due to early marriage, poor sanitation and lack of screening program. Like developed countries breast carcinoma is rising in this country. The present study showed that squamous cell carcinoma was the most common histopathological type of malignant tumors. The NICRH showed that about $60 \%$ of the male lung cancer patients were smokers and among them more than half were squamous cell carcinoma (53\%). Mutuma and Korir et al., [13] showed that squamous cell carcinoma was also noted as the most common morphological type of cancer for the cervical cancer making up $86.7 \%$ of all cervical cancer cases. In the current study, squamous cell carcinoma (35.49\%) was the highest followed by adenocarcinoma (17.70\%), ductal carcinoma of breast $(10.91 \%)$, papillary carcinoma $(9.29 \%)$. In oral cavity cancers, buccal mucosa was the commonest location followed by tongue, cheek and palate region. Current study showed that lower income generating group was the more vulnerable for malignant tumors. The present study showed that squamous cell carcinoma was the highest histopathological type of malignant tumors in smokers and nonsmoking tobacco consumers followed by adenocarcinoma. In our study the most common site of squamous cell carcinoma in smokers was oral cavity followed by oropharynx and larynx. Stomach followed by colon and rectum were common sites for adenocarcinoma. Talukder et al., [12] found that most of the benign tumors were found in breast (39.3\%) followed by ovary and myometrium of uterine body. The current study found lipoma was the top one $(35.70 \%)$ followed by fibro adenoma of breast $(25.13 \%)$, pleomorphic adenoma of salivary gland $(8.10 \%)$, leiomyoma $(4.82 \%)$.

\section{Limitations OF THE STUdy}

This was a single Centre study with small sample size. So, the results may not reflect the scenarios of the whole country.

\section{CONCLUSION AND \\ RECOMMENDATIONS}

Cigarette smoking, chewing of betel nut/betel leaf and exposure to several oncogenic microorganisms and other carcinogens are the causes of cancer. In Bangladesh few initiatives of hospital- or institutionbased tumor registry were taken in the past but with little effectiveness. These experiences suggest that a population-based or a hospital-based tumor registry is not feasible at present, and a pathology-based tumor registry can be an alternative approach as majority of the tumor diagnosis can be traced back to a pathology department. The diagnosis and treatment facilities for cancer in Bangladesh are not very well equipped. Also, the cost is high. As majority of the people are poor, many of them are not able to continue treatment after diagnosis. So cancer control should be the primary focus in developing countries like Bangladesh.

\section{REFERENCES}

1. Shopland DR, Burns DM, Garfinkel L, Samet JM. Monograph 8: Changes in cigarette-related disease risks and their implications for prevention and control. Bethesda: National Institutes of Health, National Cancer Institute, 1997.

2. Jemal A, Murray T, Samuels A, Ghafoor A, Ward E, Thun MJ. Cancer statistics, 2003. CA Cancer J Clin. 2003; 53:5-26.

3. Johnson N. Tobacco use and oral cancer: a global perspective. J Dent Educ. 2001; 65:328-339.

4. Rothman KJ. Epidemiology of head and neck cancer. Laryngoscope. 1978; 88:435-438.

5. Day GL, Blot WJ, Shore RE, et al. Second cancers following oral and pharyngeal cancers: role of tobacco and alcohol. J Natl Cancer Inst. 1994; 86:131-137.

6. Wynder EL, Mushinski MH, Spivak JC. Tobacco and alcohol consumption in relation to the development of multiple primary cancers. Cancer. 1977;40(4 Suppl):1872-1878.

7. Moore C. Smoking and cancer of the mouth, pharynx and larynx. JAMA. 1965; 191:283-286.

8. Moore C. Cigarette smoking and cancer of the mouth, pharynx and larynx. A continuing study. JAMA. 1971; 218:553- 558.

9. León X, Quer M, Diez S, Orús C, López- Pousa A, Burgués J. Second neoplasm in patients with head and neck cancer. Head \& Neck: Journal for the Sciences and Specialties of the Head and Neck. 1999 May;21(3):204-10.

10. Do KA, Johnson MM, Doherty DA, Lee JJ, Wu XF, Dong Q, Hong WK, Khuri FR, Fu KK, Spitz MR. Second primary tumors in patients with upper aerodigestive tract cancers: joint effects of smoking and alcohol (United States). Cancer Causes \& Control. 2003 Mar 1;14(2):131-8.

11. Tomek MS, McGuirt WF. Second head and neck cancers and tobacco usage. Am J Otolaryngol. 2003; 24:24-27.

12. Talukder SI, Das RK, Chowdhury SA, Rahman MT, Begum J, Nahar M, Ali MY. Histopathology Based Disease Patterns in Dinajpur. Breast. 27:135 .

13. Mutuma G, Korir A. Cancer Registry Report (2000-2002), Nairobi, 2006. Available at https:// www.healthresearchweb.org/files/CancerIncidence ReportKEMRI.pdf. 
